\title{
Stabilization Of Expansive Soil By Using A-1-B Soil In Subgrade Materials A Study In Boditi Town, Wolaita Zone, Southern Ethiopia
}

\author{
EsubalewTariku Yenialem ${ }^{1}$, Wondemagne Tadesse Borku ${ }^{2}$ \\ ${ }^{1}$ Lecturer, Department of Civil Engineering, Wolaita Sodo University, WolaitaSodo, Ethiopia \\ Email Id: esubalewtariku@yahoo.com \\ ${ }^{2}$ Lecturer, Department of Construction Technology and Management, Wolaita Sodo University, Ethiopia \\ Email Id: wondetade@gmail.com \\ *Corresponding Author: Esubalew Tariku Yenialem \\ Lecturer, Department of Civil Engineering, Wolaita Sodo university, Wolaita Sodo, Ethiopia \\ Email Id: esubalewtariku@yahoo.com
}

\begin{abstract}
In road subgrade construction, all the naturally available material cannot be utilized as sub grade material as there exists some problematic soils such as expansive soils. The problematic nature of such soils can be improved by application of stabilizing agents. [11].A sub grade soil should fulfill the minimum requirement and soils with less bearing capacity and high swelling characteristics should be treated in order to use as a sub grade material [6]. Mechanical stabilization of problematic soils with local materialsis one of the cheapest methods of improving the soils in order to use as a subgrade material [9]. Thus, in this study stabilization of Expansive soil by taking the four samples test pits, because this soil is unsuitable to use as subgrade material. To achieve these objectives four soils sample pits were selected from different representative parts of the existing sub grade. To understand the basic characteristics of this soil and stabilization there were different field and laboratory tests such as field dry density, natural moisture content, particle size distribution, specific gravity, Atterberg limits (Liquid Limit and Plastic Limit), compaction (Optimum Moisture Content and Maximum Dry Density), CBR and CBR swelling potential tests were concerned. The test results showed that the Natural Moisture Content ranges from $15.40 \%$ to $20.50 \%$, the field dry density ranges from $1.53 \mathrm{~g} / \mathrm{cc}$ to $1.61 \mathrm{~g} / \mathrm{cc}$, percentage finer ranges from $87.23 \%$ to $91.23 \%$, Specific Gravity ranges from 2.57 to 2.65, Liquid Limit ranges from $62.81 \%$ to $71.87 \%$, Plasticity Index ranges from $37.97 \%$ to $44.75 \%$, Group Index ranges from 27 to 30, Optimum Moisture Content ranges from $20.38 \%$ to $22.60 \%$, Maximum Dry Density ranges from $1.65 \mathrm{~g} / \mathrm{cc}$ to $1.68 \mathrm{~g} / \mathrm{cc}$, CBR ranges from $2.20 \%$ to $2.75 \%$ and CBR swell ranges from $3.51 \%$ to $3.94 \%$. Based on these results the study area was soil classification under A-7-6and inorganic clays with high plasticity. according to AASHTO M145 and USCS soil classification system respectively.As the result indicates that the soil samples characterized as Expansive clay soil, and those were unsuitable to use as a subgrade material for pavement construction based on [10] manual specification; thus, stabilize by mechanical method of stabilization by local materials (A-1-b soil), with different percentages ratio $(15 \%, 20 \%$ and $25 \%$ of A-1-b soil) by weight, were used to get appropriate mixing ratio, finally it was found that $25 \%$ mixing of A-1-b soil were efficient to use those as a subgrade material.
\end{abstract}

Keyword: -Soil classification, Expansive Soil and Soil Stabilization.

\section{INTRODUCTION}

\subsection{Background of the Study}

A major problem with expansive soils is their physical tendency to have large amounts of shrink and swell with changes in moisture content. If the civil engineering structure is built in expansive soils, the soil can exert extreme pressures on the walls of basements or shelters [12]. The current methods of mitigating the effects of shrink and swell include complete removal and replacement with select fill, which is expensive, thus stabilization of this soil by locally available selected material is most economical and safe for the design of civil engineering structure [1]. Expansive soils do not meet the specification requirements of many standards 
including the Ethiopian Roads Authority Standard to use it as a construction material. Thus, expansive subgrade soils may need improvement to their engineering properties by physical or chemical stabilization or modification of their problematic nature [3] .

Boditi is city in southern Ethiopia. Located in the Wolaita Zone of the Southern Nations, Nationalities, and Peoples Region, this town has a latitude and longitude of $6^{\circ} 58^{\prime} \mathrm{N} 37^{\circ} 52^{\prime} \mathrm{E}$ with an average elevation of 2050 meters above sea level. It is located in East Rift valley at a distance of $370 \mathrm{~km}$ to the south of Addis Ababa and at about $140 \mathrm{~km}$ to the west of Hawassa.

\subsection{Statement of the Problem}

Expansive soils are extensively distributed in Boditi town, and are a source of great damage to infrastructure. These soils can cause heavy economic losses, as well as being a source of risk to the population. These soils have caused persistent difficulties in civil engineering construction and are a relatively common problem in the town.[14] Construction of structure on weak or soft soil is highly risky because such soil is susceptible to differential settlements, poor shear strength, and high compressibility. These soils behave differently from other normal soils due to their tendency to swell and shrink. Because of this swelling and shrinking behavior, that cause structural damage to lightweight structures[16] such as sidewalks and driveways lifting of buildings, damage to basements, and building settlement cracks in walls and ceilings damage to pipelines and other public utilities lateral movement of foundations and retaining walls due to pressure exerted on vertical walls loss of shear strength causing instability of slopes and sub grade, etc[15]. Thus; it is essential to stabilize the expansive soil by locally available selected material (A-1b Soil) should be adopted.

\subsection{Objectives of the study}

\subsubsection{Main Objective}

Stabilization of Expansive Soil by using locally available selected material (A-1-b Soil) in Subgrade Materials A Study in Boditi Town, Wolaita Zone, Southern Ethiopia.

\subsubsection{Specific Objective}

- To investigate the properties of Boditi town expansive soil.

- To improve the strength of sub grade soil using locally available selected material (A-1-b Soil).

- To study the strength properties of soil treated with A-1-b Soil and obtain best percentage mix ratio.

\subsection{Sub-Grade Material}

\section{REVIEW OF LITERATURES}

Sub-Grade soil is the ultimate foundation of the road pavement structure which provides support to the pavement. The sub-grade materials and its different properties are very much important in the pavement design. The strength of the road sub grade for flexible pavements is commonly assessed in terms of the California Bearing Ratio (CBR) and this is dependent on the type of soil, its density, and its moisture content [5].Desirable properties of the sub grade include strength, stiffness, drainage, ease of compaction and low compressibility. These properties can have a significant influence on road performance and longterm maintenance [4].

\subsection{Expansive Soils}

Expansive soils are typically clayey soils that undergo large volume changes in direct response to moisture changes in the soil [3].

\subsubsection{Identification of Expansive Soils}

I. Mineralogical Identification Expansiveness of a soil is governed by the type and proportion of clay minerals it contains.[6] Knowing the type and proportion of the clay mineral in a soil gives a clue on the swelling potential. The swell shrink behavior of expansive soils depends on the type of minerals present within the clay. 
II. Direct Methods The swelling pressure and volume changes of soils are measured directly using representative undisturbed samples.

III. Indirect Methods These are simple and more practical methods to identify expansive soils. The indirect tests conducted include the Atterberg limits and grain size distribution which help determining the activity of clay (the ratio of plasticity index (PI) to the percentage of clay fractions finer than $2 \mu \mathrm{m}$ sieve size) present in the sample and degree of expansiveness.

Table 1. Swelling Potential of Soils Based on Liquid Limitof Soil[11].

\begin{tabular}{|l|l|}
\hline Liquid Limit \% & Classification \\
\hline $0-20$ & Non-Swelling \\
\hline $20-35$ & Low-Swelling \\
\hline $35-50$ & Medium-Swelling \\
\hline $50-70$ & High-Swelling \\
\hline $70-90$ & Very High-Swelling \\
\hline$>90$ & Extra High-Swelling \\
\hline
\end{tabular}

Table 2 Relationship between Swelling Potential and Plasticity Index of Soil[3].

\begin{tabular}{|l|l|}
\hline Plasticity index, PI (\%) & Swelling Potential \\
\hline $0-15$ & Low \\
\hline $10-35$ & Medium \\
\hline $20-55$ & High \\
\hline 35 and above & Very high \\
\hline
\end{tabular}

\subsection{Stabilization of the Properties of Expansive Soils}

Soil stabilization is a process whereby increased strength and stability of the soil is attained mainly by mechanical or chemical means [8]. Chemical stabilization is mixing of soil with one or a combination of admixtures and mechanical stabilization is a process by which the gradation of soil is improved by the incorporation of another material which affects only the physical properties of the soil. The most common improvements attained through stabilization include better soil gradation, reduction of plasticity index or swelling potential, increase in the durability and strength[16]. The proportion of the stabilizing material exceeds $10 \%$ and may be as high as 50\% [7]. Thus, in this study mechanical stabilization of the soil by locally available selected material (A-1-b soil) mixed with expansive subgrade soils (A-7-6 soil) in appropriate proportional ratio by weight used.

\section{RESEARCH METHODOLOGY}

\subsection{Field Works}

- Reconnaissance study of the area is done and the locations of test pits are selected.

- Field GPS readings are taken to locate the ordinate of sampling area and four sampling points are selected.

Table 3. Soil Sample Location of the Study Area

\begin{tabular}{|l|l|l|l|l|l|}
\hline S/No & Location & $\begin{array}{l}\text { Depth } \\
(\mathrm{m})\end{array}$ & Northing & Easting & $\begin{array}{l}\text { Elevation } \\
(\mathrm{m})\end{array}$ \\
\hline TP1 & Boditi City Stadium & 2 & $6^{\circ} 57^{\prime} 19^{\prime \prime}$ & $37^{\circ} 51^{\prime} 37^{\prime \prime}$ & 2038 \\
\hline TP2 & Boditi Bus Station & 1.5 & $6^{\circ} 57^{\prime} 15^{\prime \prime}$ & $37^{\circ} 51^{\prime} 22^{\prime \prime}$ & 2050 \\
\hline TP3 & Boditi Seventh Day Adventist Church & 2 & $6^{\circ} 57^{\prime} 02^{\prime \prime}$ & $37^{\circ} 51^{\prime} 41^{\prime \prime}$ & 2019 \\
\hline TP4 & Boditi Mosque & 1.5 & $6^{\circ} 57^{\prime} 16^{\prime \prime}$ & $37^{\circ} 51^{\prime} 30^{\prime \prime}$ & 2045 \\
\hline $\begin{array}{l}\text { A-1-b } \\
\text { Soil }\end{array}$ & HaretoBurkito Kebele & 1.5 & $7^{\circ} 04^{\prime} 40^{\prime \prime}$ & $37^{\circ} 58^{\prime} 5^{\prime \prime}$ & 1811 \\
\hline
\end{tabular}




\subsection{Laboratory Work}

Table 4 The Soil Laboratory Tests; (ERA, Site Investigation Manual, 2013)

\begin{tabular}{|c|c|c|}
\hline \multirow[t]{2}{*}{ Test Category } & \multirow[t]{2}{*}{ Name of Test } & $\begin{array}{c}\text { Test } \\
\text { Designation }\end{array}$ \\
\hline & & ASTM \\
\hline \multirow{5}{*}{ Index properties } & $\begin{array}{l}\text { Test Method for Determination of Water (Moisture) Content of Soil } \\
\text { by Direct Heating }\end{array}$ & D 2216 \\
\hline & Test Method for Specific Gravity of Soils & D854 \\
\hline & Method for Particle-Size Analysis of Soils & D 422 \\
\hline & Test Method for Classification of Soils for Engineering Purposes & $\begin{array}{l}\text { D } 2487 \\
\text { D } 3282\end{array}$ \\
\hline & $\begin{array}{l}\text { Test Method for Liquid Limit, Plastic Limit, and Plasticity Index of } \\
\text { Soils }\end{array}$ & D 4318 \\
\hline Compaction & $\begin{array}{l}\text { Test Method for Laboratory Compaction of Soil Using Modified } \\
\text { Effort }\end{array}$ & D 1557 \\
\hline Strength & $\begin{array}{l}\text { Test Method for CBR } \quad \text { (California } \\
\text { LaboratoryCompacted Soils }\end{array}$ & D 1883 \\
\hline
\end{tabular}

\section{RESULTS AND DISCUSSION}

\subsection{Field and Laboratory Test Results of the Soil Samples}

Table 5.Field dry density, natural moisture content and specific gravity test Results

\begin{tabular}{|c|l|l|l|c|}
\hline Sample No. & $\begin{array}{l}\text { Field bulk } \\
\text { density } \\
(\mathrm{g} / \mathrm{cc})\end{array}$ & $\begin{array}{l}\text { Natural } \\
\text { Moisture } \\
\text { Content } \%\end{array}$ & $\begin{array}{l}\text { Field dry density } \\
(\mathrm{g} / \mathrm{cc})\end{array}$ & $\begin{array}{l}\text { Specific } \\
\text { Gravity }\end{array}$ \\
\hline TP1 & 1.85 & 20.5 & 1.53 & 2.58 \\
\hline TP2 & 1.84 & 19.7 & 1.54 & 2.62 \\
\hline TP3 & 1.87 & 17.2 & 1.59 & 2.57 \\
\hline TP4 & 1.86 & 15.4 & 1.61 & \\
\hline
\end{tabular}

Table 6. The Grain Size Analysis Test Results of the Soil Samples

\begin{tabular}{|l|l|l|l|l|l|l|}
\hline \multirow{2}{*}{$\begin{array}{l}\text { Sample } \\
\text { No. }\end{array}$} & \multicolumn{3}{|c|}{ Coarser grain size soil } & \multicolumn{3}{c|}{ Finer grain size soil } \\
\cline { 2 - 7 } & Gravel \% & $\begin{array}{c}\text { Coarse } \\
\text { Sand \% }\end{array}$ & Fine Sand \% & Silt \% & Clay \% & $\begin{array}{l}\text { Clay Fraction } \\
\text { Size }<0.002 m m\end{array}$ \\
\hline TP1 & 2.5 & 7.12 & 2.76 & 31.71 & 55.90 & \\
\hline
\end{tabular}




\begin{tabular}{|l|l|l|l|l|l|r|}
\hline TP2 & 0 & 8.30 & 4.45 & 29.13 & 58.12 & 39.72 \\
\hline TP3 & 0 & 8.00 & 4.77 & 28.71 & 58.52 & 41.00 \\
\hline TP4 & 0 & 5.00 & 3.77 & 30.72 & 60.51 & 43.62 \\
\hline
\end{tabular}

Table 7. Atterberg Limit, Compaction, CBR Swell and CBR Test Results.

\begin{tabular}{|l|l|l|l|l|l|l|l|l|l|l|}
\hline $\begin{array}{l}\text { Sample } \\
\text { No. }\end{array}$ & LL \% & PL \% & PI \% & LI $_{\mathrm{I}}$ & $\begin{array}{l}\text { AASHTO } \\
\text { Soil Clas. }\end{array}$ & $\begin{array}{l}\text { Soil } \\
\text { type }\end{array}$ & $\begin{array}{l}\text { MDD } \\
\text { g/cc }\end{array}$ & OMC \% & $\begin{array}{l}\text { CBR } \\
\text { Swell \% }\end{array}$ & $\begin{array}{l}\text { CBR } \\
\%\end{array}$ \\
\hline TP1 & 62.81 & 24.51 & 38.3 & -0.11 & A-7-6(27) & clay & 1.67 & 20.38 & 3.51 & 2.75 \\
\hline TP2 & 64.68 & 26.71 & 37.97 & -0.12 & A-7-6(27) & clay & 1.68 & 20.50 & 3.70 & 2.66 \\
\hline TP3 & 71.87 & 27.12 & 44.75 & -0.13 & A-7-6(29) & clay & 1.65 & 22.60 & 3.88 & 2.53 \\
\hline TP4 & 68.3 & 25.4 & 42.9 & -0.12 & A-7-6(30) & clay & 1.66 & 20.81 & 3.94 & 2.20 \\
\hline
\end{tabular}

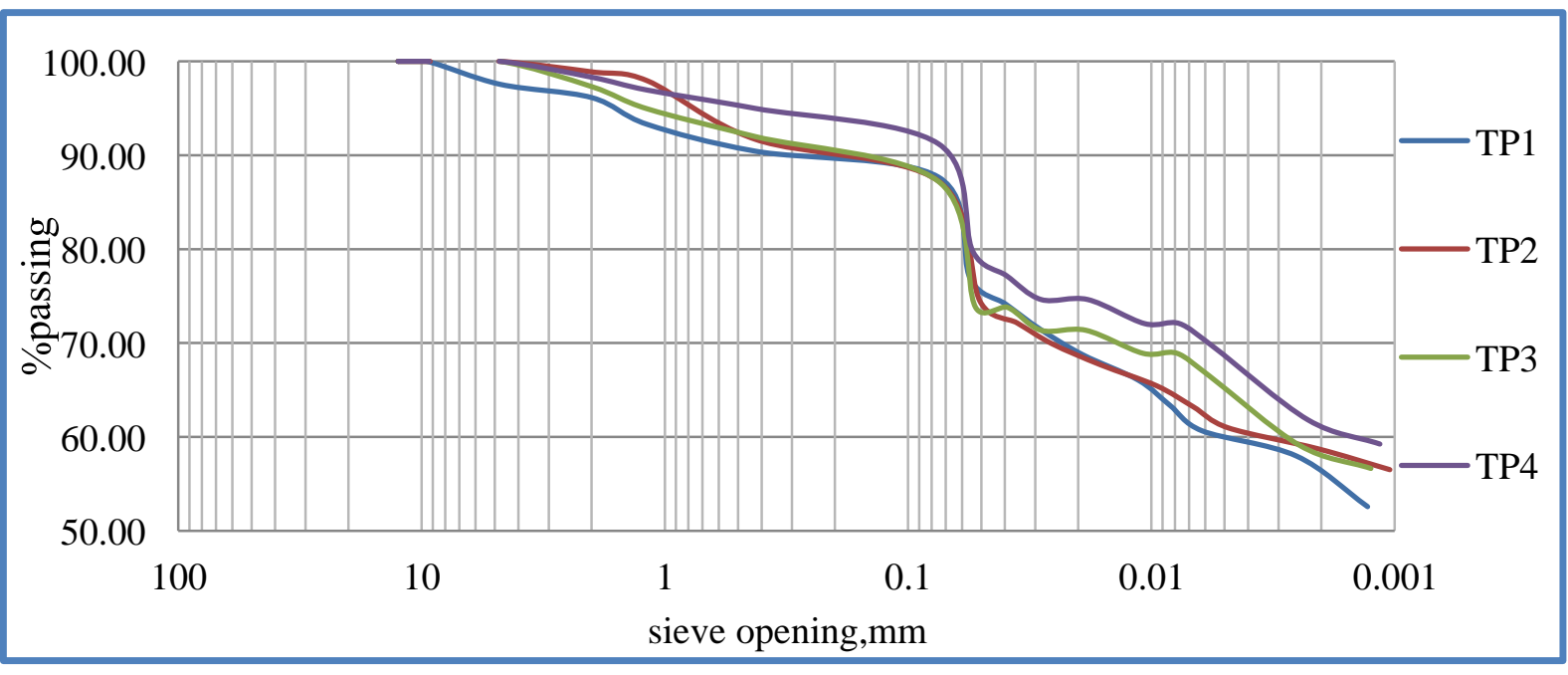

Figure 1 Gradation Curves of the Study Area

AASHTO SOIL CLASIFICATION CHART

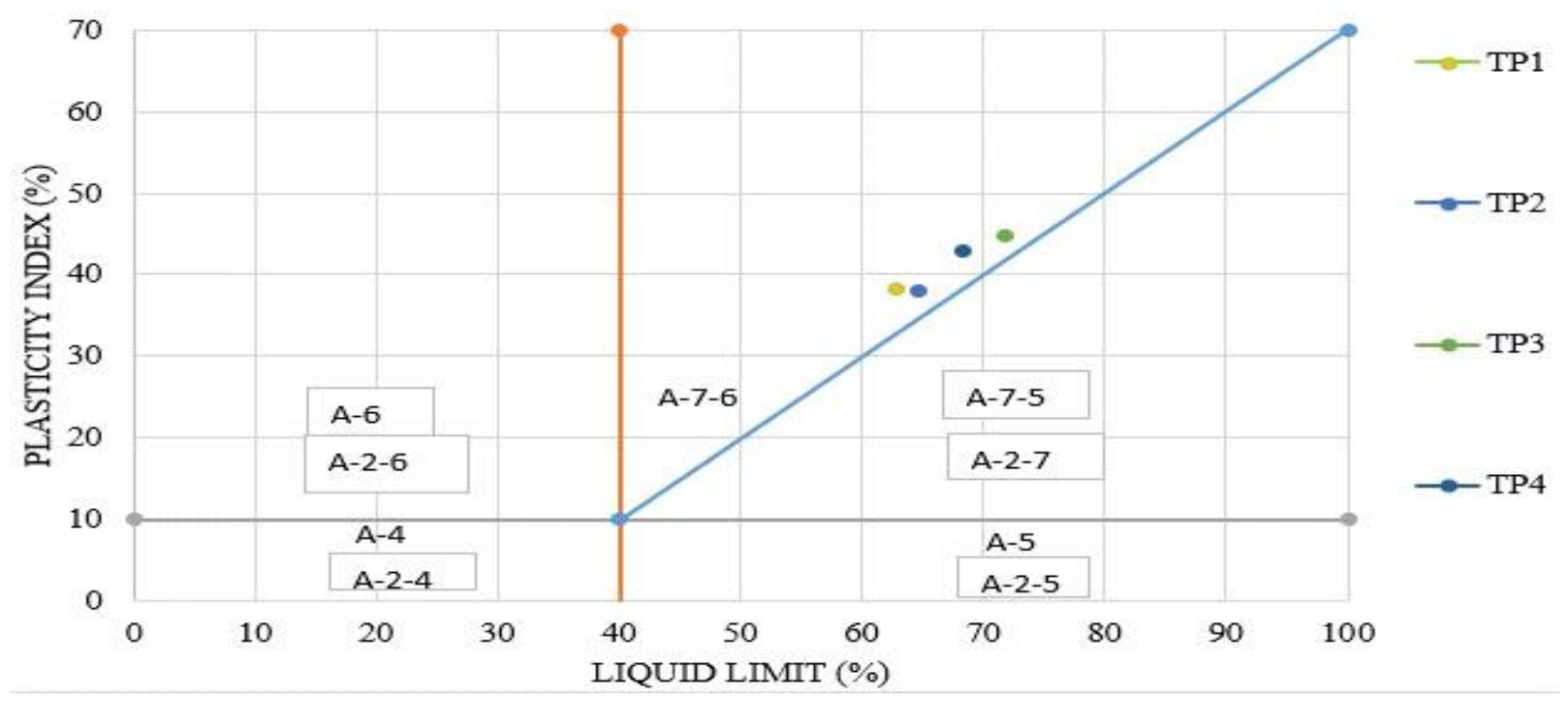


Figure 2 Soil Classification Chart According to AASHTO System

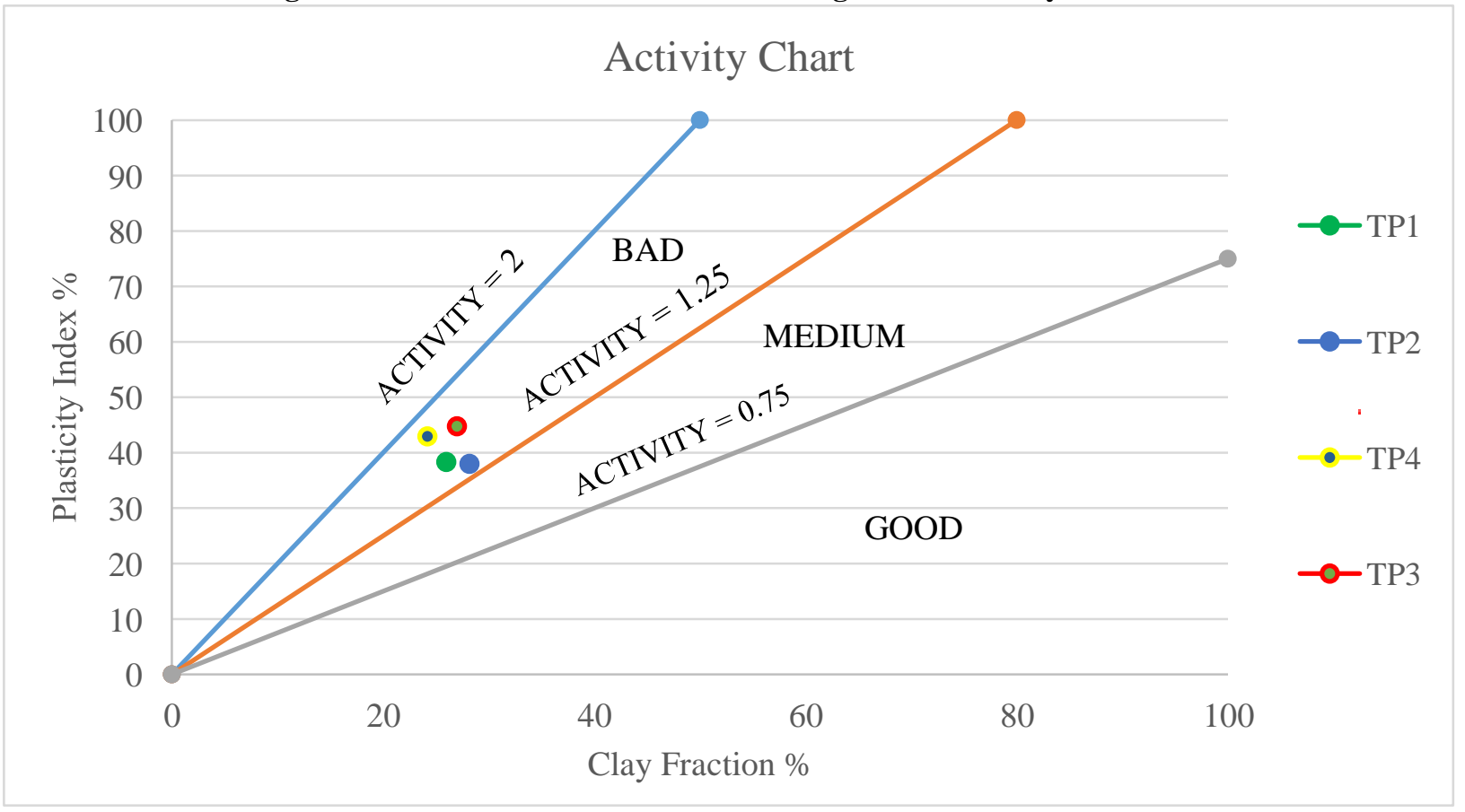

Figure 3. Soil Classification Based on Activity Chart for the Study Area

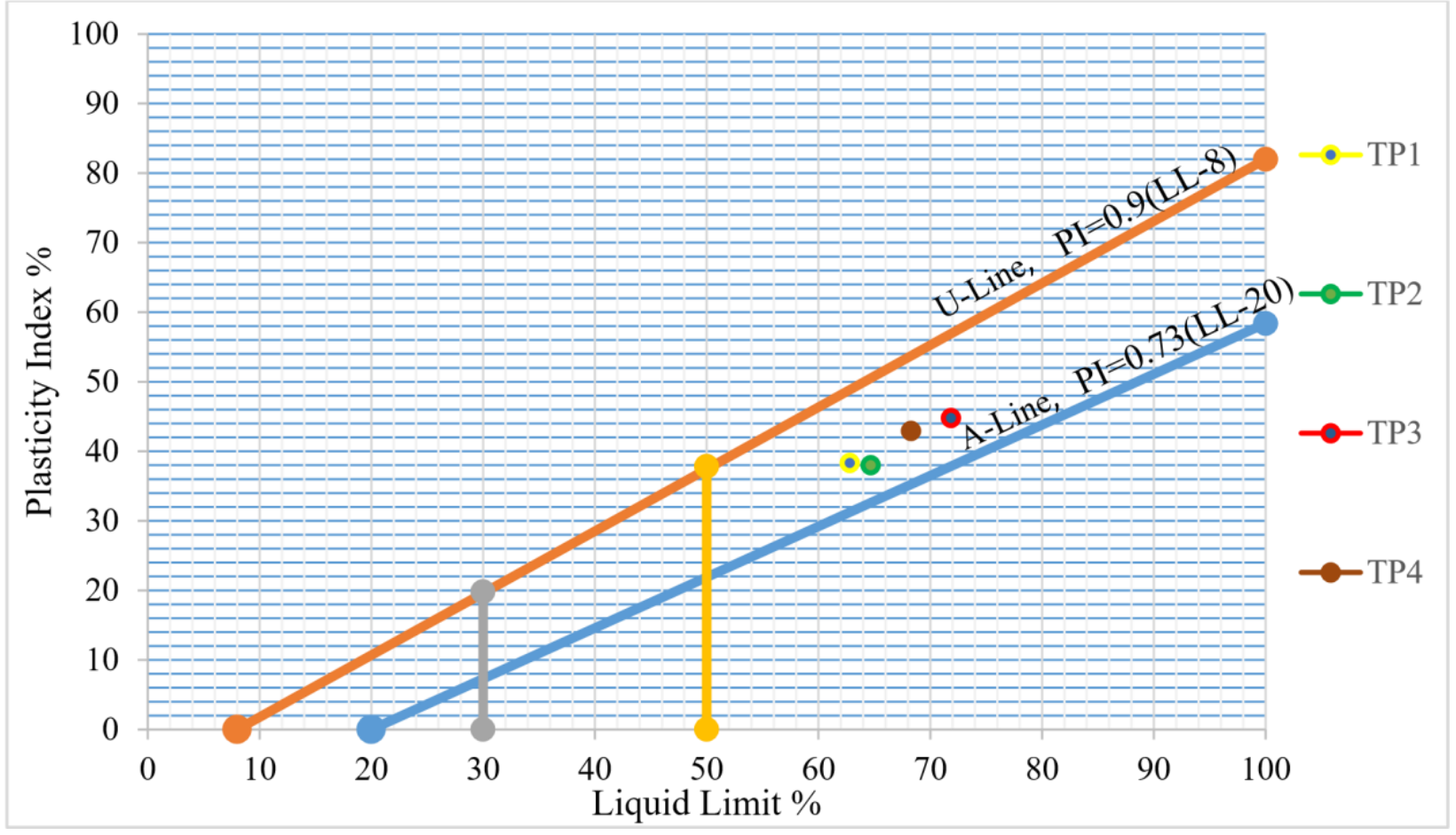

Figure 1 Soil Classification Based on Plasticity Chart for the Study Area. 


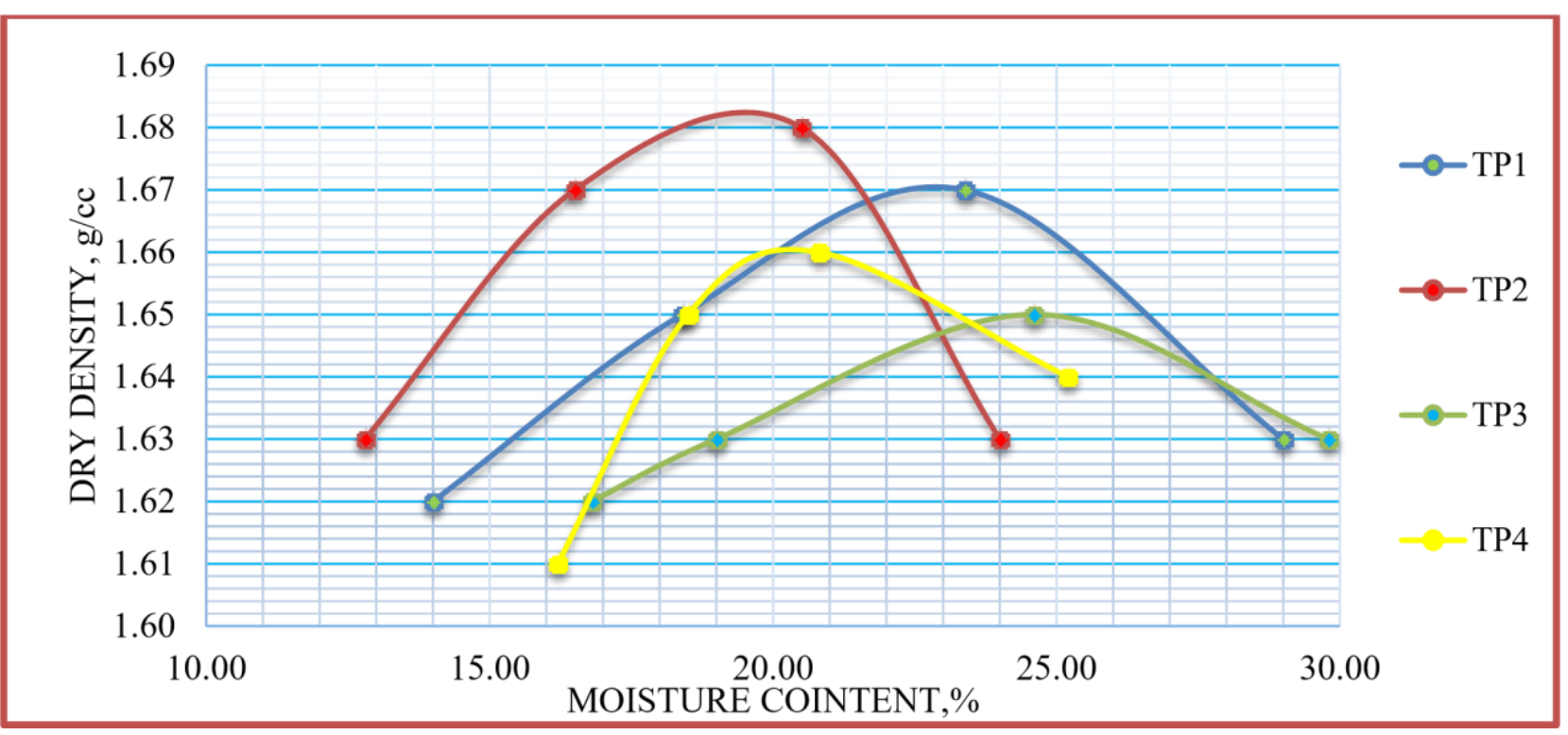

Figure 5. Moisture Density Relations of the Soil Sample

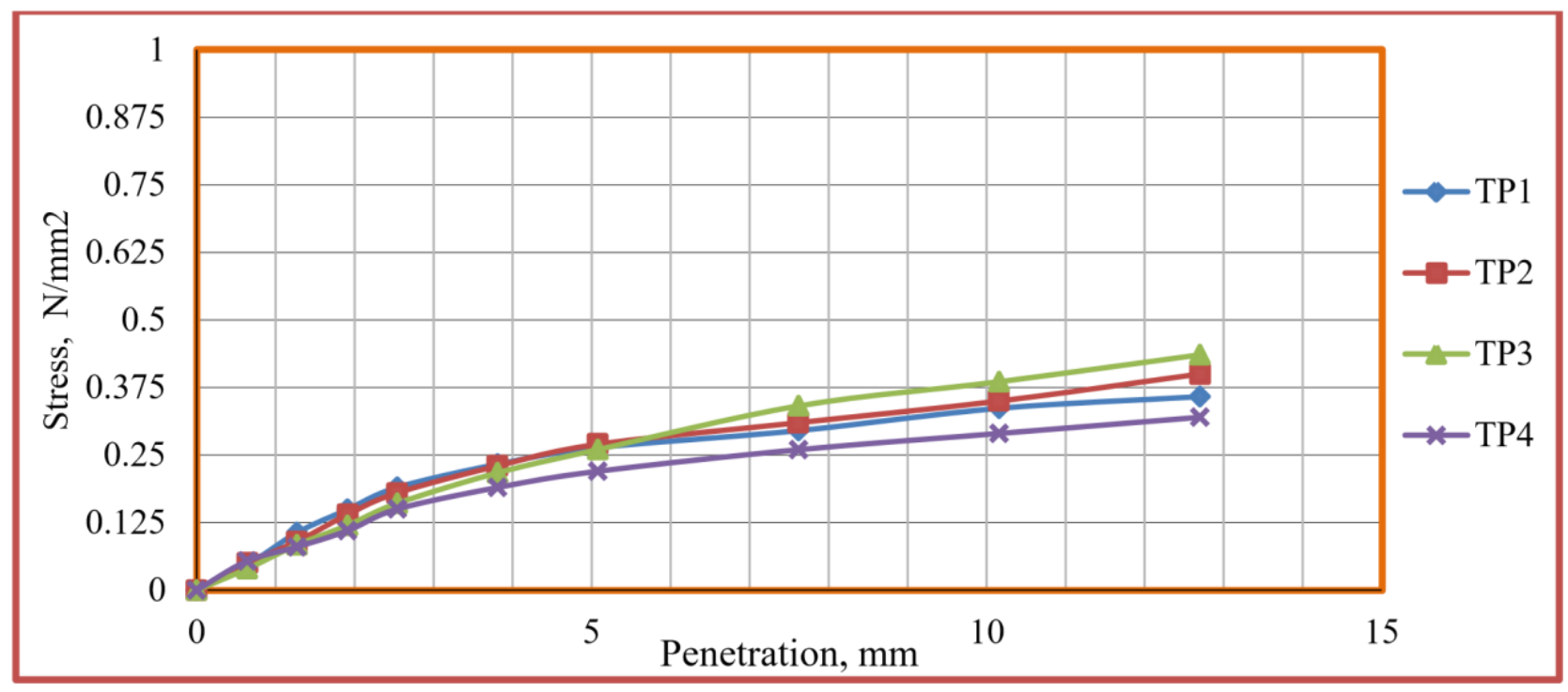

Figure 6. Stress Vs Strain Curves.

Generally; these soil samples were unsuitable to use as a subgrade material based on specification; thus, those soils should be treated with appropriate improving method before using as a subgrade soil[5]. 
4.2 Stabilization of Expansive Soil by Adding A-1-b SoilRatio by Mass.

Table 1. The Grain Size Analysis for TP 1 with $15 \%, 20 \%$ and $25 \%$ of A-1-b Soil

\begin{tabular}{|l|l|l|l|l|l|}
\hline \multirow{2}{*}{ Samples } & \multirow{2}{*}{ Gravel\% } & \multicolumn{2}{|c|}{ Sand \% } & \multicolumn{2}{c|}{ Finer \% } \\
\cline { 3 - 6 } & \multicolumn{2}{|l|}{$\begin{array}{l}\text { Coarse } \\
\text { Sand \% }\end{array}$} & Fine Sand \% & Silt \% & Clay \% \\
\hline A-1-b & 13.56 & 45.36 & 38.79 & 2.29 \\
\hline Stabilization of TP1 & \multicolumn{5}{l}{} \\
\hline TP1 & 2.5 & 7.12 & 2.76 & 31.71 & 54.90 \\
\hline TP1 + 15\% A-1-b Soil & 5.0 & 14.12 & 7.70 & 26.06 & 47.12 \\
\hline TP1 + 20\% A-1-b Soil & 8.5 & 20.16 & 11.72 & 20.62 & 39.00 \\
\hline TP 1 + 25\% A-1-b Soil & 10.3 & 26.14 & 15.94 & 16.70 & 30.91 \\
\hline
\end{tabular}

Table 9. The LL, PL, Compaction, CBR Swell and CBR Tests for TP1 with 15\%, $20 \%$ and 25\% A-1-b Soil

\begin{tabular}{|l|l|l|l|l|l|l|l|l|}
\hline Sample No. & LL \% & PL \% & PI \% & GI & $\begin{array}{l}\text { MDD } \\
\text { g/cc }\end{array}$ & OMC \% & CBR Swell \% & CBR \% \\
\hline A-1-b Soil & - & - & 0 (NP) & 0 & 2.20 & 8.30 & 0.29 & 53.53 \\
\hline TP1 & 62.81 & 24.51 & 38.30 & 27 & 1.67 & 20.38 & 3.51 & 2.75 \\
\hline $\begin{array}{c}\text { TP1+ 15\% } \\
\text { A-1-b Soil }\end{array}$ & 50.90 & 22.20 & 28.70 & 17 & 1.75 & 17.31 & 2.8 & 4.1 \\
\hline $\begin{array}{l}\text { TP1+ 20\% } \\
\text { A-1-b Soil }\end{array}$ & 41.07 & 20.11 & 20.96 & 13 & 1.78 & 16.26 & 2.4 & 4.70 \\
\hline $\begin{array}{l}\text { TP1+ 25\% } \\
\text { A-1-b Soil }\end{array}$ & 31.25 & 13.14 & 16.92 & 9 & 1.81 & 15.22 & 1.89 & 5.41 \\
\hline
\end{tabular}

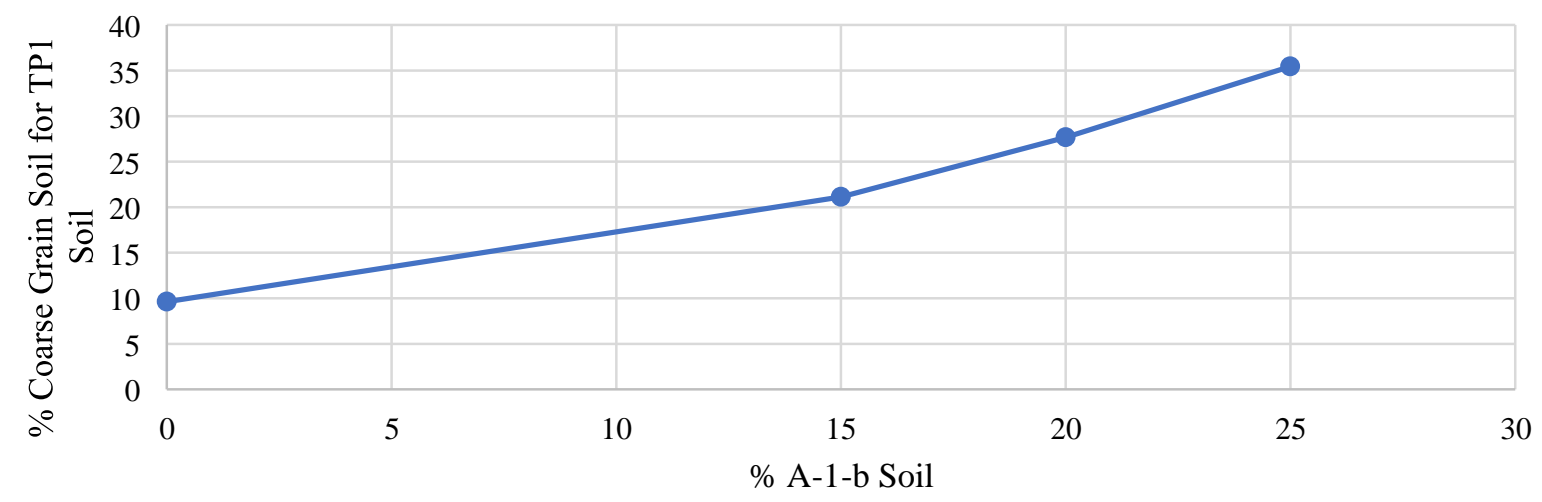

Figure 2.Increase in A-1-b Soil with Increase in Course Grained Soil of TP1. 


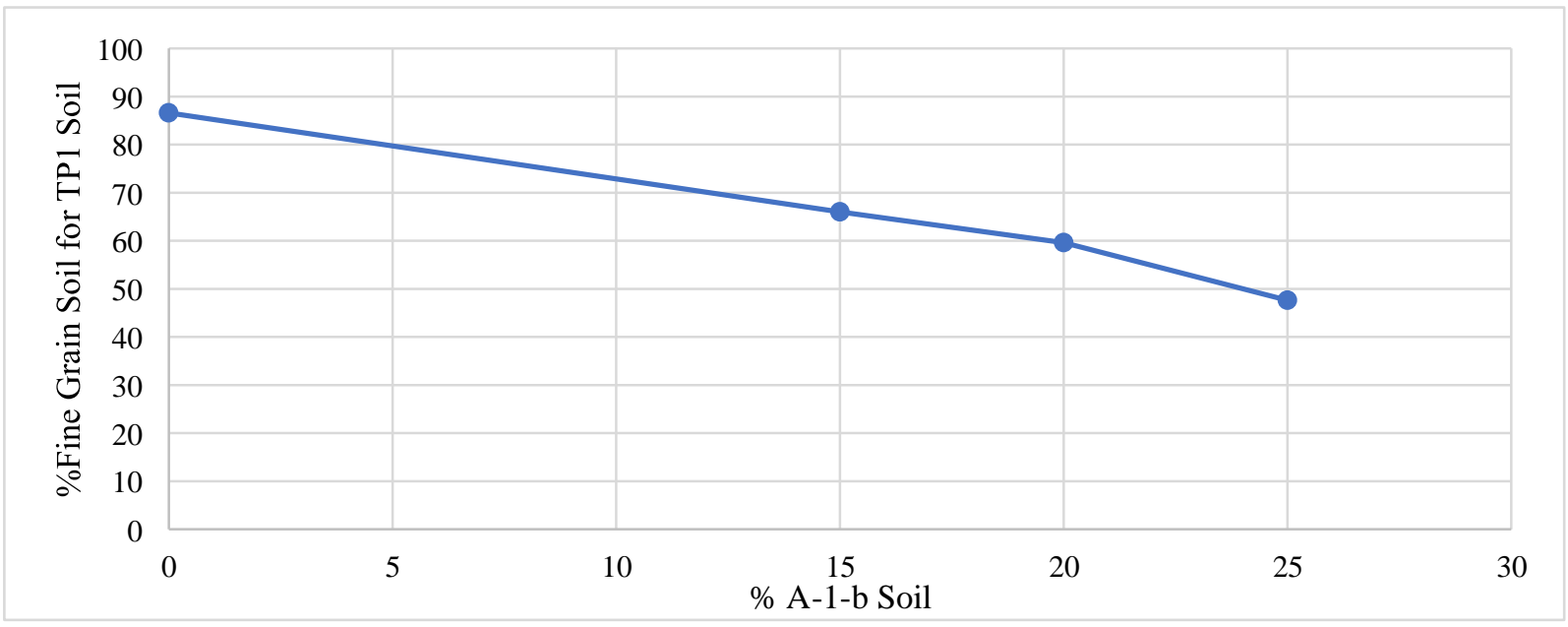

Figure 3.Increase in A-1-b soil with Decrease in Fine Grained Soil for TP1.

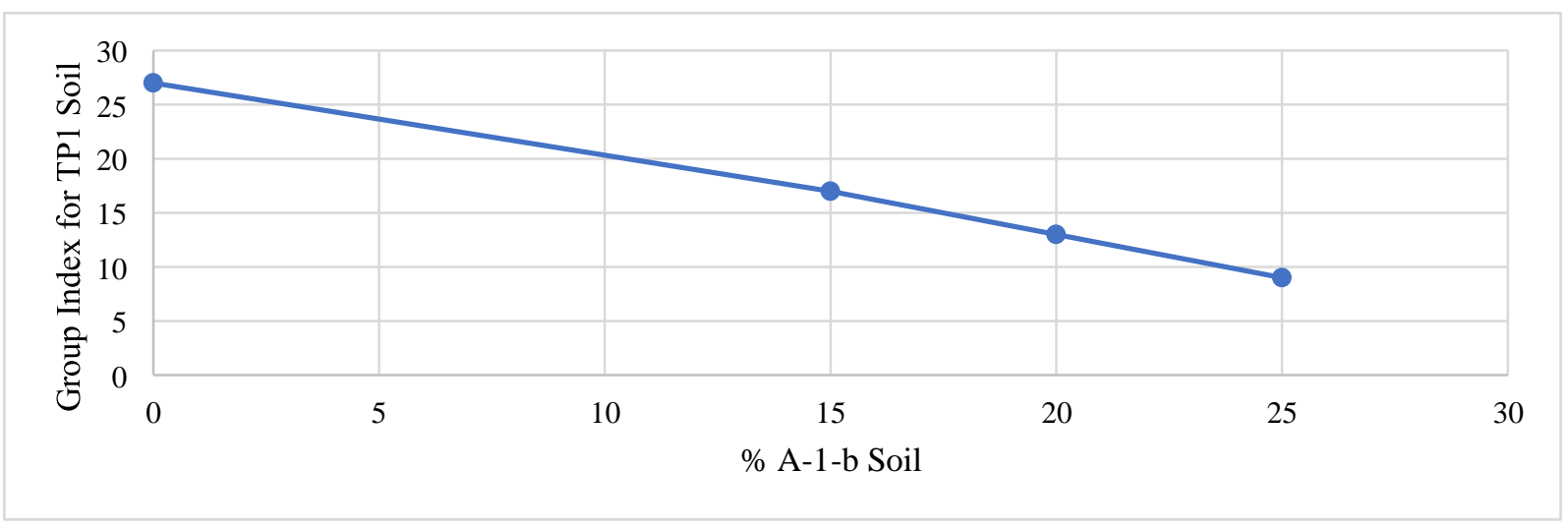

Figure 4.Increase in A-1-b Soil with Decrease in GI value of TP1 soil.

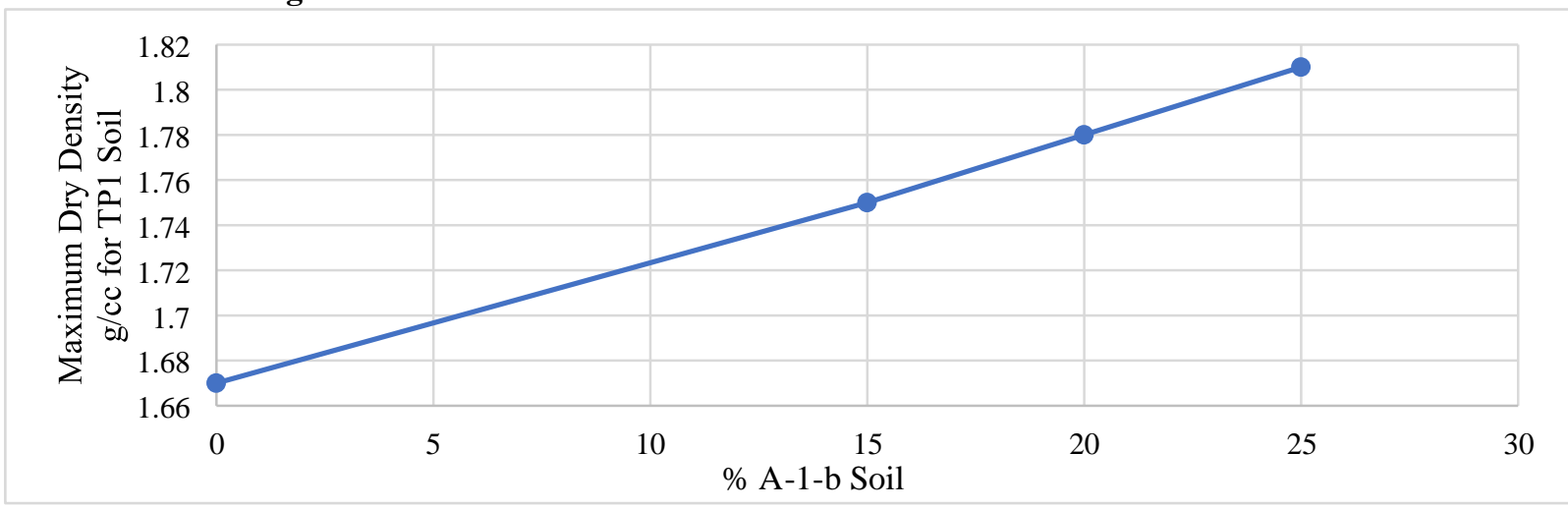

Figure 5.Increase in A-1-b Soil with Increase in Maximum dry density of TP1 soil. 


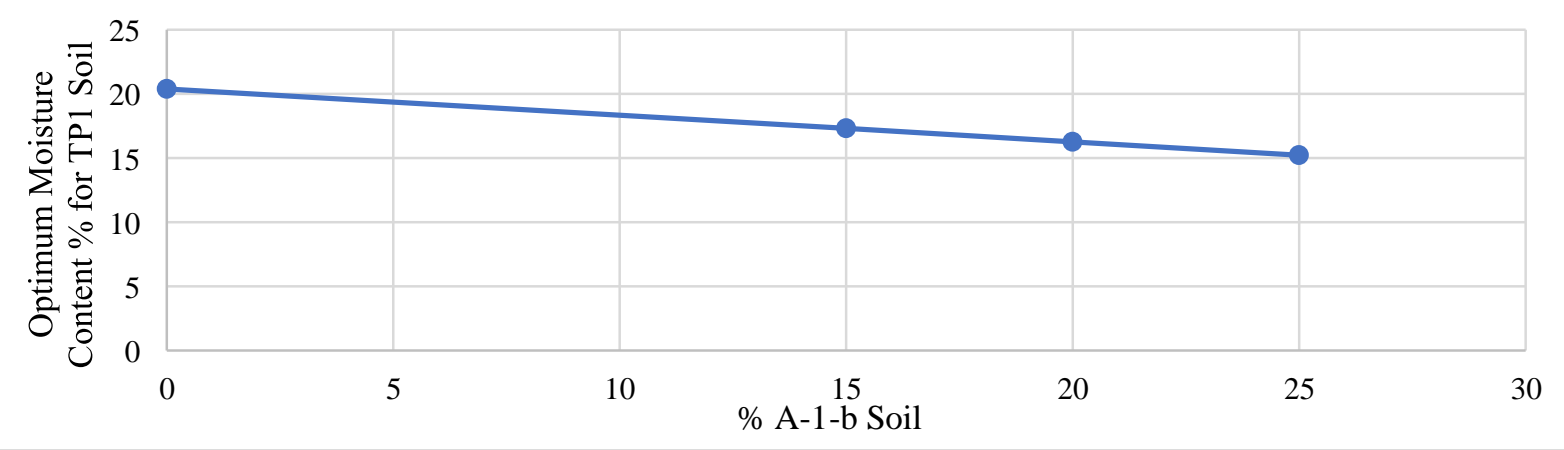

Figure 6. Increase in A-1-b Soil with Decrease in Optimum Moisture Content of TP1 soil.

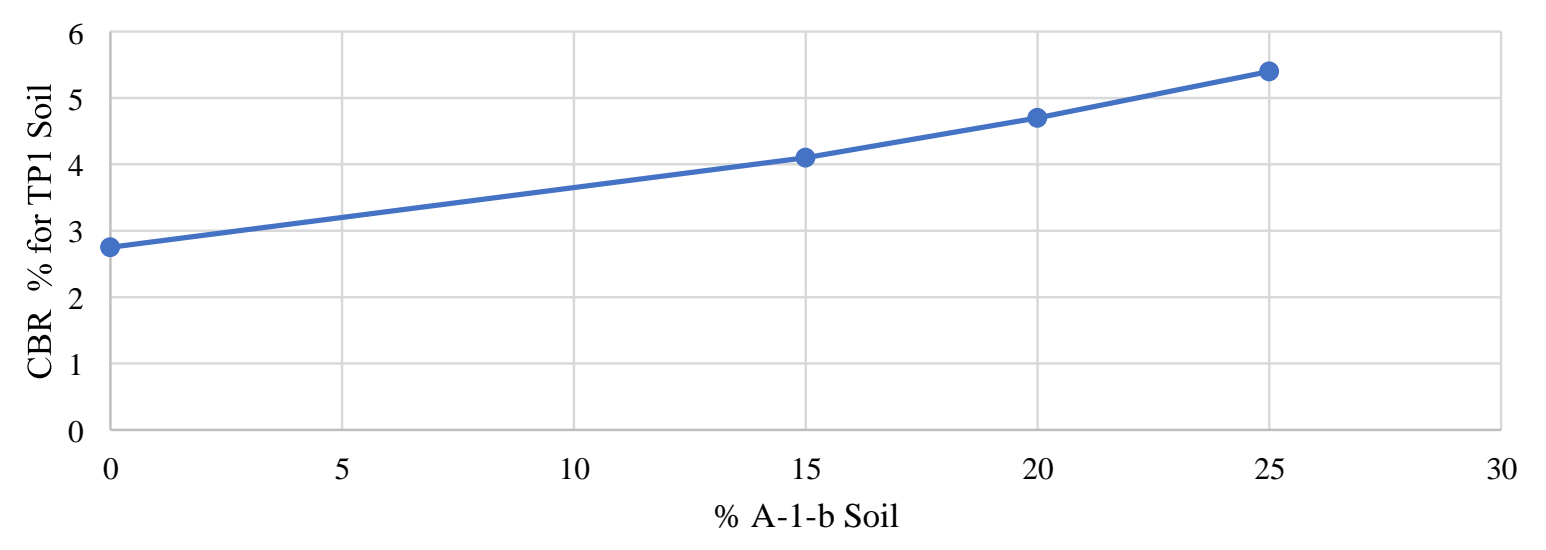

Figure 7.Increase in A-1-b Soil withIncrease in CBR value of TP1 soil.

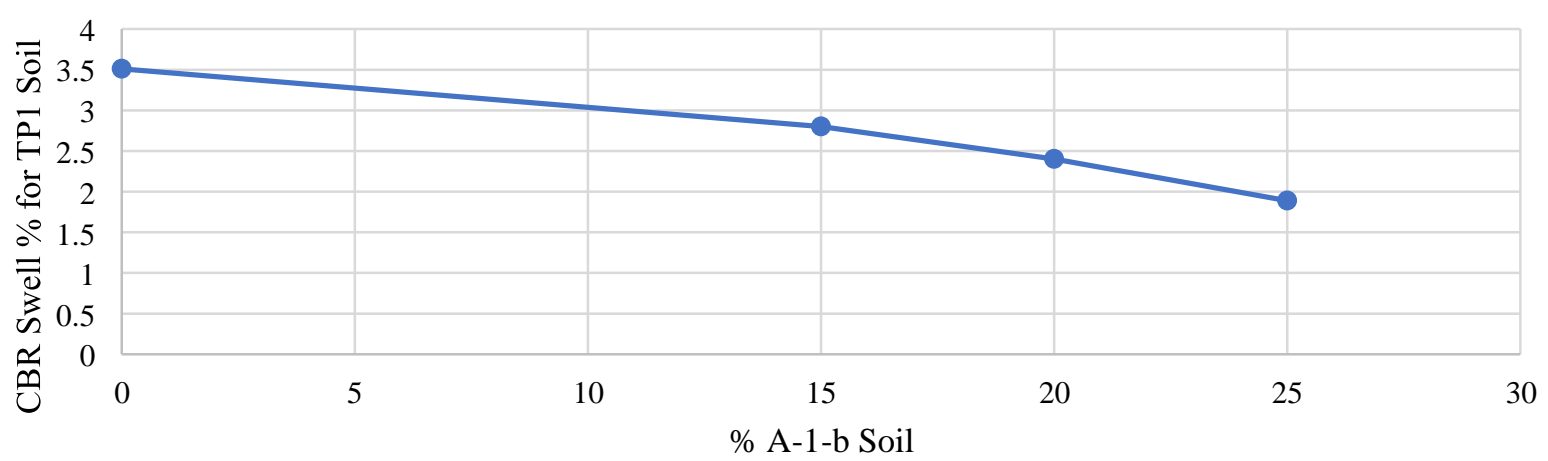

Figure 8.Increase in A-1-b Soil withDecrease in CBR Swell of TP1 soil. 
Table 20. The Grain Size Analysis Test Results for TP2, TP3 and TP4 by Adding 25\% A-1-b Soil.

\begin{tabular}{|l|l|l|l|l|l|}
\hline & & \multicolumn{2}{|c|}{ Sand \% } & \multicolumn{2}{c|}{ Finer \% } \\
\hline \multirow{2}{*}{ Samples } & \multirow{2}{*}{ Gravel\% } & \multicolumn{2}{l|}{} \\
\cline { 3 - 6 } & & $\begin{array}{l}\text { Coarse Sand } \\
\%\end{array}$ & Fine Sand \% & Silt \% & Clay \% \\
\hline TP2 + 0\% A-1-b Soil & 0 & 8.30 & 4.45 & 29.13 & 58.12 \\
\hline TP2 + 25\% A-1-b Soil & 7.42 & 29.85 & 17.96 & 15.17 & 29.54 \\
\hline TP 3 + 0\% A-1-b Soil & 0 & 8.00 & 4.77 & 28.71 & 58.52 \\
\hline TP3 + 25\% A-1-b Soil & 6.98 & 30.21 & 16.87 & 17.28 & 28.66 \\
\hline TP4 + 0\% A-1-b Soil & 0 & 5.00 & 3.77 & 30.72 & 60.51 \\
\hline TP4 + 25\% A-1-b Soil & 7.83 & 27.42 & 15.94 & 18.18 & 30.63 \\
\hline
\end{tabular}

Table 11.The LL, PL, Compaction, CBR Swell and CBR Tests for TP2, TP3 and TP4 with 25\% A-1-b Soil.

\begin{tabular}{|l|l|l|l|l|l|l|}
\hline Parameter & $\begin{array}{l}\text { TP2 + 0\% A- } \\
\text { 1-b Soil }\end{array}$ & $\begin{array}{l}\text { TP2 + 25\% } \\
\text { A-1-b Soil }\end{array}$ & $\begin{array}{l}\text { TP3 + 0\% } \\
\text { A-1-b Soil }\end{array}$ & $\begin{array}{l}\text { TP3 + 25\% } \\
\text { A-1-b Soil }\end{array}$ & $\begin{array}{l}\text { TP4 + 0\% } \\
\text { A-1-b Soil }\end{array}$ & $\begin{array}{l}\text { TP4 + 25\% A- } \\
\text { 1-b Soil }\end{array}$ \\
\hline LL $(\%)$ & 64.68 & 33.54 & 71.87 & 34.84 & 68.30 & 32.97 \\
\hline PL $(\%)$ & 26.71 & 15.61 & 27.12 & 16.76 & 25.40 & 14.83 \\
\hline PI $(\%)$ & 37.97 & 17.93 & 44.75 & 18.08 & 42.90 & 18.14 \\
\hline GI & 27 & 10 & 29 & 11 & 30 & 12 \\
\hline MDD (g/cc) & 1.68 & 1.83 & 1.65 & 1.79 & 1.66 & 1.82 \\
\hline OMC $(\%)$ & 20.50 & 16.50 & 22.60 & 17.94 & 20.81 & 17.10 \\
\hline CBR Swell $(\%)$ & 3.70 & 1.90 & 3.88 & 1.92 & 3.94 & 1.95 \\
\hline CBR $(\%)$ & 2.66 & 6.21 & 2.53 & 5.91 & 2.20 & 5.07 \\
\hline
\end{tabular}

\section{CONCLUSIONS}

This study is to improve the index and engineering properties of expansive soils by mechanical stabilization method with adding A-1-b by considering safety and economy.

For this study field investigation, field dry density tests and laboratory tests conducted for NMC, grain size analysis, specific gravity, Atterberg limits, compaction, CBR and CBR swell tests were done, finally stabilize using 15\%, 20\% and 25\% A-1-b Soilratio by mass with expansive soil, all the test procedures were based on ASTM laboratory tests standards.

From the study the following findings are deduced: -

1. The soils of the studied area are grouped A-7-6with a poor soil as per AASHTO classification system, Soils in this group have high liquid limits. Moreover, as per USCS soil classification system all of the soils sample are grouped as inorganic clays with high plasticity [5].

2. The CBR test result shows that the soil have a sub grade strength property of poor depending on with Group index value [1].

3. The improvements on engineering properties of expansive soil to use as a subgrade material, were observed on gradation size, plasticity index, group index, maximum dry density, optimum moisture content, CBR swell potential and CBR values.

4. The soil classification of HaretoBurkaitokebele were A-1-b soil as per AASHTO soil classification and non-plasticity behavior in addition to this it has a good bearing capacity; thus, using this as a blending material [1].

5. Finally,the engineering properties of expansive subgrade soils of the study area are improved by blending with addition of $25 \%$ of A-1-b soil on problematic subgrade soils of the study area is bringing the problematic subgrade soil to the minimum requirement as a subgrade material stated by ERA pavement design manual [4]. 


\section{REFERENCES}

[1] AASHTO. (2013). Standard Specification for Transportation Materials and Methods of Testing and Sampling. . Washington DC.

[2] Austroads. (14 August 2008). Technical Basis of Aust Roads Guide to Pavement Technology, Part 2 Pavement Structural Design.

[3] Chen F.H. (1988). Foundation on Expansive Soils.

[4] ERA. (2002). Pavement Design Manual Volume I Flexible Pavement and Gravel Roads.

[5] Dr.A. Paulmakesh, Dec 2021, "Analysis of uncertainty in a construction project" YMER journal, Vol 20,Issue 12, pg.no 324-332.

[6] ERA. (2002). Standard Technical Specification of Subgrade, Subbase, Base and Gravel Wearing Courses.

[7] ERA. (2013). Pavement Design Manual Volume I Flexible Pavements.

[8] Yimam Mohammed, A. Paulmakesh, Bereket Admasu amd Saliha Shukri, Oct 2021, "Relationship between California Bearing Ratio and Other Geotechnical Properties of Sub grade Soils", ICEPAE 2021,Journal of Physics Conference Series, Vol 2040(1):012024, doi:10.1088/1742596/2040/1/012029, pg.no 1-13.

[9] Jones, D., Rahim, A., Saadeh, S. and Harvey, T., 2010. Guid Lines for the Stabilization of Subgrade Soils in California. California: University of California Pavement ResearchCenter.

[10] Yimam Mohammed Yimer, A. Paul Makesh and SalihaShukri Muhammed, Oct 2021, "Prediction of undrained shear strength and correlation in between soil parameters", ICEPAE 2021, Journal of Physics Conference Series, Vol 2040(1):012029, doi:10.1088/1742-6596/2040/1/012024 pg.no 1-8.

[11] Lucian, C., 2008. Geotechnical Aspects of Buildings on Expansive Soils in Kibaha, Tanzania,.Stochholm, Sweden: Doctoral Thesis.

[12] Dr.A.Paulmakesh, Gizachew Markos Makebo April 2021, "Management of contracts for Durable structures" Innovations, Number 64,Pg 1044-1054

[13] Rani, C. S., 2013. Investigation on Engineering Properties of Soil-mixture Comprising of Expansive Soils and a Cohesive Non-swelling Soil. International Journal of Innovations inEngineering and Technology, 2(3), pp. 1-6.

[14] Rao B. (2007). Steps to Improve Roads on Black Cotton Soils.

[15] Skempton. (1953). The Colloidal Activity of Clays. Third Internationa Conference on Soil Mechanics and Foundation Engineering.

[16] Dr.A. Paulmakesh, Yimam Mohammed Yimer, April 2021, "Implementation of Project Management for Strategy Realisation" Journal of University shanghai for Science and Technology, Volume 23, Issue 10,Pg.No 887-892 